\title{
INTERNATIONAL DEVELOPMENT IN TRANSITION
}

Sophie Harman and David Williams

School of Politics and International Relations

Queen Mary University London

$\underline{\text { S.harman@qmul.ac.uk }}$

David.williams@qmul.ac.uk

\begin{abstract}
International development is in a period of transition. While the outcome of this is as yet unclear, this article argues that there are at least four areas in which the project of international development is changing. First, there is a debate, especially within the World Bank, about development strategy, particularly in terms of the balance between states and markets. Second, and partly following from this, there is increasing evidence of a shift in lending, particularly towards infrastructure. Third, 'non-traditional' aid donors and new forms of private philanthropy are playing a more significant role and in turn this offers developing countries a new range of choices about what kinds of development assistance they receive. Fourth, partly as a result of this, aid relations are changing as a result of the renewed agency of developing states, particularly in sub-Saharan Africa, and shifts towards increased South-to-South co-operation are growing as evidenced by increased funding from regional development banks and increased trade flows. The article reviews these changes and suggests a series of questions and challenges that flow from them for analysts of international development, developing countries and traditional aid donors.
\end{abstract}

Key words: International Development, Aid, World Bank 
The project of international development is in a period of transition. ${ }^{1}$ The various dimensions of this transition are relatively clear, even if the outcome is much less so. The first aim of this article is to outline and suggest some explanations for what we take to be the main dimensions of this transition. These are changes in development thinking, particularly with regard to the role of the state; changing donor priorities around 'big' and 'small' development; the changing donor landscape and a new age of choice for developing countries; and changing aid relationships that creates greater autonomy for developing countries. We suggest that such changes are linked together in ways that are leading to some quite substantial shifts in the policies and practices of international development. The second aim of this article is to signal some of the important questions and debates that arise when we take notice of these shifts. First, there are explanatory questions related to how we capture the dynamics involved in these areas of change and their relations with one another. Second, there are questions about what the new demands will be for developing country governments and aid donors in this new environment. Third, and related, there are questions about what lessons we might draw from past experiences, in the sense that for some of the ideas and practices we see assuming a new significance in the contemporary period, there are at least parallels in the past. Finally, there are questions about the future trajectory of this transition, where we are transiting to, and whether it will be sustained and amplified in the future.

\section{Changes in International Development}

There is a sense in which the project of international development is always changing. Development agencies are always producing new reports, developing new lending programmes and certainly over the last twenty years or so, they have dramatically expanded the scope of their work into new areas. Our concern here is not with this kind of change, important though it is. It is rather with what we might call more fundamental changes in how the process of development is understood, in how foreign aid is contributes to development, and in the forms of the relationship between development agencies and recipient states. Viewed in this way we think it is possible to identify four related elements that suggest there is something significant happening within international development. First, a shift in developing thinking that raises important questions about the utility of

\footnotetext{
1 We very are grateful to Clive Gabay, Ray Kiely, Christopher May, James Scott and two anonymous reviewers for very helpful comments and suggestions.
} 
market-based policy prescriptions and re-emphasises the role of the state in the development process. Second, a return to 'big' development, especially in terms of a renewed stress on infrastructure and a move away from 'small' development as embodied in the Millennium Development Goals (MDGs). Third, a set of changes in the donor environment that has created a new era of choice for aid recipient states based on pluralism and autonomy. Fourth, and related to all of these, a shift in the relationship between traditional development agencies and aid recipient states that reinforces this autonomy. In all of these areas there are complications and ambiguities, but we think that taken together they indicate some possibly very significance changes in the project of international development.

\section{Changing development thinking: states and markets}

In recent years there has emerged a substantial debate about the relative role of states and markets in the development process. This debate has been taking place particularly within the World Bank, and given that the Bank has always played a lead role in shaping development thinking in the wider development community this is obviously significant. ${ }^{2}$ One element of this has been a series of reflections on the developmental record of the last 15 years or so. Some of the conclusions of this represent a fundamental critique of the development policy that dominated most western development agencies in the 1990s and into the first part of the 2000s. As early as 2005 the World Bank was arguing that 'growth entails more than the efficient use of resources. Growth entails structural transformation.'3 Structural transformation here refers to more than just changes in economic policy or

\footnotetext{
2 See for example Michael Gavin and Dani Rodrik, 'The World Bank in Historical Perspective,' American Economic Review, Paper and Proceedings May, 1995, pp. 329-334 and Nicholas Stern and Francisco Ferreira, 'The World Bank as "intellectual Actor", ' in Devesh Kapur et al, eds, The World Bank: its first half century (Washington DC: Brookings Institution, 1997), pp. 523-609. ${ }^{3}$ World Bank, Economic Growth in the 1990s, (Washington: World Bank, 2005), p10. The term 'structural transformation' is something of a new buzzword, although it is clear that there are differences in how this term is understood. The World Bank held a conference in 2011 under the title 'Structural Transformation and Economic Growth'. In October 2013 ODI and the DfIDESRC Growth Research Programme held a conference under the title 'Structural Transformation, Growth and Development in Low Income Countries'. See also Justin Yifu Lin, 'From Flying Geese to Leading Dragons: new Opportunities and Strategies for Structural Transformation in Developing Countries', World Bank Policy Reseat Working Paper, no. 5702, Washington, DC, World Bank, June 2011 and Berthold Herrendorf, Richard Rogerson and Akos Valentinyi, 'Growth and Structural Transformation', in Philippe Aghion and Steven Durlauf (eds), The Handbook of Economic Growth vol. 2B (Amsterdam: Elsevier, 2014) pp. 855-942.
} 
political institutions. ${ }^{4}$ It is a dynamic process that involves wholesale changes in social relations and patterns of production and consumption. This understanding of development already signals some kind of return to the ideas associated with the development economics of the 1950s. ${ }^{5}$ More important than this is what the report says about how such development is to be achieved: 'what matters for growth is less the degree to which policies approximate the ideal than the extent to which a given development strategy is able to mobilize the creative forces of society and achieve ever higher levels of productivity. ${ }^{6}$ In a profound criticism of market based development policy, the report says:

In retrospect it is clear that in the 1990s we often mistook efficiency gains for growth. The 'one-size fits all' policy reform approach and the belief in 'best practices' exaggerated the gains from improved resource allocation and ... proved to be both theoretically incomplete and contradicted by the evidence. ${ }^{7}$

In some ways the World Bank here was catching up with the wider debate about neoliberalism and structural adjustment. ${ }^{8}$ While the literature here is extensive and diverse, it does seem to justify several conclusions. First, that the kinds of policies associated with structural adjustment are better at restoring macro-economic stability to crisis-ridden states than stimulating long-term growth. Second, better performing developing states often used 'unorthodox' economic policies. Third, that the Bank and the IMF were not sufficiently attuned to the particular circumstances of individual developing countries. In addition, of course, institutions such as UNCTAD consistently and continuously challenged the dominance of market-based policy prescriptions produced by the Bank. ${ }^{9}$

\footnotetext{
${ }^{4}$ David Williams, The World Bank and Social Transformation in International Politics: liberalism, governance and sovereignty (London: Routledge, 2008), p86.

${ }^{5}$ See Albert O. Hirschman, The Strategy of Economic Development, (New Haven and London: Yale University Press, 1958). This classic book is quoted in the report.

${ }^{6}$ World Bank, Economic Growth in the 1990s, p. 11.

${ }^{7}$ World Bank, Economic Growth in the 1990s, p. 11.

${ }^{8}$ For example see William Easterley, 'What did Structural Adjustment adjust? the association of policies and growth with repeated IMF and World Bank adjustment loads,' Journal of Development Economics, 76: 1, 2001, pp. 1-22.

${ }^{9}$ See, for example, UNCTAD, Economic Development in Africa Report 2001: performance, prospects and policy issues (New York: UNCTAD, 2001). In another sign of the growing importance of 'structural transformation' see UNCTAD, Economic Development in Africa Report 2012: structural transformation and sustainable development in Africa (New York: UNCTAD, 2012).
} 
The criticisms made about the effectiveness of markets as a basis for development policy obviously raises questions about what kinds of policy prescriptions might be more appropriate. The report quoted above made a number of more positive arguments. First, an argument for the desirability of policy flexibility: in other words countries should have space to adapt and adopt policies that seem best suited to their particular circumstances. Second, the report argued that there were some 'essential' functions' that characterize all successful developing countries, but that these functions - rapid accumulation of capital, efficient resource allocation, technological progress, and sharing the benefits of growth could be achieved by varied and various policies. Third, it argued that government discretion should be managed, not replaced by rules, and that there should be a pragmatic and incremental approach to public sector governance. ${ }^{10}$

The role of the state in the economy and in the process of development more generally is central to these new concerns and this issue has been debated extensively within the Bank. We can identify two strands here. The first strand understands the issue to be one of the appropriate balance between considerations of 'market failure' and 'state failure." ${ }^{11}$ This has been one of the longest standing debates within development economics. In the postwar period much more stress was placed on market failures within developing countries and hence the need for a more interventionist state. The 1980s counter-revolution in turn placed more emphasis on state failures, and hence stressed the desirability of relying on the market mechanism for allocating economic resources. ${ }^{12}$ There is no doubt that, in the words of Devarajan and Kanbur 'the pendulum has swung back in the direction of the statist dominance of the $1940 \mathrm{~s}$ and 1950s. ${ }^{13}$ This way of understanding the problem is largely a technical one in the sense that it invites detailed consideration of the forms of market and state failure in individual developing countries and attempts to devise policies to overcoming these. This way of understanding the issue of the role of the state is related to, but also rather different from that articulated by the former World Bank Chief Economist Justin Lin. In his book, New Structural Economics, Lin sought to address the shortcomings of previous development policies that, according to Lin, have not delivered

\footnotetext{
10 World Bank, Economic Growth in the 1990s, passim.

${ }^{11}$ Shantayanan Devarajan and Ravi Kanbur, 'The Evolution of Development Strategy as balancing market and government failure' Charles H Dyson School of Applied Economics and Management, Cornell University, Working Paper 09, 2013.

12 John Toye, Dilemmas of Development (Oxford: Blackwell, 1987).

${ }^{13}$ Devarajan and Kanbur, 'The Evolution of Development Strategy,' p. 4.
} 
on growth or provided effective policy guidance for developing countries. ${ }^{14}$ The approach he articulated sought to go beyond neoclassical structural and neoliberal approaches to development economics to recognise that while the market is fundamental to resource allocation, innovation, and industrial diversity, the government also needs to play a significant role. ${ }^{15}$ For Lin the issue is not simply that of the appropriate balance between state failure and market failure, but more broadly the role or responsibility of the state in consciously driving and shaping the process of structural change. One way of thinking about this is to take note of how the experience of different regions has shaped the debate. Devarajan is World Bank Chief Economist for the Africa region (and for Kanbur too Africa has been central) and reflecting on the development experience of that region demonstrates the profound consequences of 'state failure' and generates perhaps more caution in advocating a return to statist development (something we reflect on below). Lin on the other hand has spent considerable time reflecting on the development experience of East Asian states where the issue was not just the extent of government intervention (to correct market failures) but the more fundamental one that the state led and directed the process of development as part of a national economic and political project.

Some of these arguments have been around before, particularly in the context of reflections on the development success of the East Asian 'miracle' economies. It is particularly striking though how the World Bank is debating a different way of understanding these economies than it was prepared to countenance in the mid-1990s, when it emphasised export promotion and macro-economic management as key factors. ${ }^{16}$ These arguments have also been put forward by a number of other economists. Dani Rodrik, for example, has argued that neoliberal reforms 'were too obsessed with deadweight-loss triangles and reaping efficiency gains from eliminating them, and did not pay enough attention to stimulating the dynamic forces that lie behind the growth process. Seeking efficiency gains does not amount to a growth strategy. ${ }^{17}$ What had previously been marginal

\footnotetext{
14 Justin Yifu Lin, 'New structural economics: a framework for rethinking development' World Bank Policy Research Working Paper No. 5197, 2010; Justin Yifu Lin and David Rosenblatt, 'Shifting patterns of economic growth and rethinking development,' World Bank Policy Research Working Paper, No. 6040, 2012.

${ }^{15}$ Lin, 'New Structural Economics.'

16 World Bank, World Development Report: infrastructure for development, (Washington: World Bank, 1994); Robert Wade, 'Japan, The World Bank, and the Art of Paradigm Maintenance: the East Asian Miracle in political perspective,' New Left Review, 217:May/June ,1996, pp. 3-36.

${ }^{17}$ Dani Rodrik, 'Goodbye Washington Consensus, Hello Washington Confusion? a review of The World Bank's Economic growth in the 1990s: Learning from a decade of reform,' Journal of Economic Literature XLIV, 2006, p. 975, emphasis in original.
} 
views have been drawn into the World Bank, sometimes in quite concrete ways - Rodrik, for example, has talked at the Bank, written papers, and contributed to Bank blogs. ${ }^{18}$ The Commission on Growth and Development report of 2008 also demonstrated a renewed commitment to the state: 'just because governments are sometimes clumsy and sometimes errant, does not mean they should be written out of the script. On the contrary, as the economy grows and develops, active, pragmatic governments have crucial roles to play., ${ }^{19}$ We can see some evidence of the impact of these kinds of arguments in the 'revival' of five-year national development strategies and economic planning in a number of countries. ${ }^{20}$

Reflection on market-based policy prescriptions and the associated debate about the role of the state has been shaped of course by changes in the broader international environment. The examples of China in particular, but also Brazil (and others) have amply demonstrated that successful development (by some measures at least) can be achieved using a mix of polices quite different from those embodied in the Washington Consensus. ${ }^{21}$ Indeed, it has been argued that almost all 'successful' developing countries have used 'unorthodox' policies. ${ }^{22}$ These examples show the centrality of the state not just in directing specific investment spending or intervening in specific markets, but more generally leading the process of development through the formulation and implementation of a development strategy. The financial and economic crisis has also called into question some of the underlying assumptions and arguments about the utility of the 'market' and also led to debates about the use of unorthodox policies such as capital controls, even within the IMF. ${ }^{23}$ In addition, many developing countries have experienced much better economic performance than Europe or the US since the crisis. In this environment, the self-

\footnotetext{
${ }^{18}$ His arguments are collected in Dani Rodrik, One Economics, Many Recipes: globalization, institutions and growth (Princeton: Princeton University Press, 2008).

19 Commission on Growth and Development, Growth Report: strategies for sustain growth and inclusive development (Washington DC: World Bank, 2008), p. 4.

${ }^{20}$ Sam Hickey, 'Beyond 'Poverty Reduction through Good Governance': the new political economy of development in Africa,' New Political Economy, 17:5, 2013, pp. 683-690; Martin Khor, 'Reviving economic planning in Africa' Third World Network, http://twnside.org.sg/title2/gtrends/gtrends417.html (accessed May 2013).

${ }^{21}$ Dani Rodrik, 'Trading in Illusions,' Foreign Policy, 123: March-April, 2001, pp. 54-62.

${ }^{22}$ Nancy Birdsall, Dani Rodrik and Arvind Subramanian, 'How to Help Poor Countries,' Foreign Affairs, 84:4, 2005, pp.136-152.

23 Jonathan D. Ostry, et al., Capital Inflows: The Role of Controls (Washington DC: IMF, 2010); IMF, The Liberalization and Management of Capital Flows: An Institutional View, (Washington DC: IMF, 2012), http://www.imf.org/external/np/pp/eng/2012/111412.pdf (accessed March 2013).
} 
confident assertions of the superiority of more market-oriented prescriptions may no longer be possible. As a World Bank report says, 'a multi-polar world requires a new multipolar approach to knowledge. ${ }^{24}$ This is just one example of how the Bank is trying to adapt to changing external conditions. ${ }^{25}$

Perhaps the most significant process of reflection among the big DAC bilateral aid agencies has been seen in the UK Department for International Development (DfID), although here the issue has been more about the processes and practices of aid allocation. This has led to at least four recent notable changes. First, we have seen the 'UK Aid: From the British People' branding of activities and support. This moves away from the presentation of DfID as a more benevolent donor that stresses the ownership of both aid and projects by the recipient state. Second, we have seen a closer alignment of DfID priorities with the foreign policy objectives of the Foreign and Commonwealth Office (FCO) and potentially the Ministry of Defence with discussions over development aid being used for defence spending. ${ }^{26}$ Promotion of peace, stability, and containing weapons proliferation are among DfID's current development priorities. This has led to what Pugh et al call the 'developmentalisation of security' that sees a shift away from interventionist development policies and a reorientation of agency away from the intervenor to the intervened. ${ }^{27}$ Third, DfID has placed renewed emphasis on aid effectiveness that is performance-based and emphasises payment by results. The fourth, and perhaps most telling change has arisen as a result of the 2011 Bilateral and Multilateral Technical Reviews. The bilateral review report recommended DfID close bilateral programmes in 16 countries that had 'graduated' or where UK aid was not warranted (China and Russia are perhaps two of the notable countries included in this category). ${ }^{28}$ The multilateral review considered

\footnotetext{
${ }^{24}$ World Bank, 'Research for Development: A World Bank Perspective on Future Directions for Research' World Bank Policy Research Working Paper, No.5437, 2010.

25 World Bank Annual Report 2013

http://documents.worldbank.org/curated/en/2013/06/18278949/world-bank-annual-report$\underline{2013}$

${ }^{26}$ Tom Cargill, 'Back to business? UK policy and African agency' in W. Brown and S. Harman, eds., African Agency in International Politics (Abingdon: Routledge, 2013), pp65-78, Nicholas Watt, 'David Cameron gives green light for aid cash to go on military,' The Guardian, 21 ${ }^{\text {st }}$ February 2013, http://www.guardian.co.uk/politics/2013/feb/21/david-cameron-aid-military (accessed May 2013).

${ }^{27}$ Jonathan Pugh, Clive Gabay, and Alison Williams, 'Beyond the securitisation of development: the limits of intervention, developmentalisation of security and repositioning of purpose in the UK Coalition Government's Policy Agenda,' Geoforum 44, 2012, pp. 193-201.

${ }_{28}$ DfID. 'Bilateral aid review: technical report' (London: DfID, 2011) https://www.gov.uk/government/uploads/system/uploads/attachment data/file/214110/FIN
} 
the 'value for money' being provided by different multilateral institutions, with the performance of institutions being characterised as 'Poor' (UNIFEM), 'Adequate' (UNAIDS), 'Good' (UNDP), or 'Very Good' (GAVI). ${ }^{29}$ The result of this classification was an increase in funds to some institutions, e.g. UNICEF and IDA. But four organisations were put in 'special measures, ${ }^{, 30}$ and four organisations had their funding withdrawn. ${ }^{31}$ While these changes do not suggest a sustained reflection on the nature of 'development' or the role of the state, they do indicate an awareness and understanding of the changing context of UK aid provision, both internationally and domestically.

For other donors it is not clear very much is changing. The European Union, for example, is continuing to finance development projects in much the same way as it has since 2005 with a 'project approach' to development that includes some sector and budget support. The emphasis within EuropeAid remains focused on the MDGs, equitable development, and good governance and country ownership. ${ }^{32}$ In the United States, while there is some evidence of a recognition of the changed external environment within which USAID works, the list of policy priorities articulated in the 'Policy Framework' produced in 2011 reflects a fairly standard list of issues that shows a good deal of continuity with policy priorities of the 1990s - education, health, democracy, rights, governance, women's empowerment - with the addition of several security issues - countering extremism and insurgency and people trafficking. ${ }^{33}$ This indicates, perhaps, that there is less policy cohesion in the current period than was the case during the late $1990 \mathrm{~s}$, for example. ${ }^{34}$ The current picture then is complicated. There is something important happening in terms of debating development policy and some recognition that development policy needs to adapt to changing external circumstances. But it is also far from clear what exactly, if

AL BAR 20TECHNICAL 20REPORT.pdf (accessed December 2013). The countries are: Angola, Bosnia, Burundi, Cameroon, Cambodia, China, Gambia, Indonesia, Iraq, Kosovo, Lesotho, Moldova, Niger, Russia, Serbia, and Vietnam.

${ }^{29}$ DfID. 'Multilateral aid review' (London: DfID, 2011) https://www.gov.uk/government/uploads/system/uploads/attachment data/file/67583/multil ateral aid review.pdf (accessed December 2013).

${ }^{30}$ UNESCO, FAO, Commonwealth Secretariat, and IOM

${ }^{31}$ UN-HABITAT, ILO, UNIDO, and UNISDR. For further information see DfID 'Multilateral aid review: taking forward the findings of the UK multilateral aid review'

https://www.gov.uk/government/uploads/system/uploads/attachment data/file/224993/MA

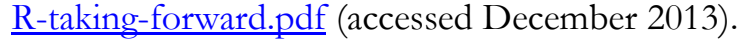

32 EuropeAid. http://ec.europa.eu/europeaid/index en.htm (Accessed December 2013).

33 USAID, Policy Framework, 2011-15 (Washington, DC: USAID, 2011).

${ }^{34}$ David Williams, International Development and Global Politics: history, theory and practice (London: Routledge, 2012), pp. 141-44. 
anything, might issue from this in terms of a new kind of development consensus. However, and importantly, there have been some changes in patterns of development funding that have points of connection with some of the debates about development policy. We do not claim that these changes result simply from a rethinking of policy, but they are at least congruent with it and they certainly help to reinforce the idea that the project of international development is changing.

\section{Changing donor priorities: 'big' vs. 'small' development}

There is clear evidence of a shift in donor priorities towards infrastructure and middleincome country investment with an emphasis on the role of the state as the driver of such projects. This shift stands in some tension with the development objectives exemplified by the MDGs. This tension has been captured by a senior World Bank staffer as the contrast between 'Big Development' and 'Small Development.' 35 'Big Development' (structural transformation) requires 'wholesale investments in roads, ports, agriculture, education, justice, finance and public health - and, crucially, the corresponding government ministries to plan, fund, implement and assess it all.' In this vision the private sector is obviously important, but to function effectively it requires 'consistent and legitimate institutional arrangements ensuring that the interests of elites, entrepreneurs and everyday citizens align.' In short, he says, 'Big Development seeks to build national systems.' 'Small Development', by contrast, is 'inspired less by transformational visions of entire countries' and more by the material plight of individuals and groups. 'Small Development' does not focus on building national systems ... but on compensating for the failures of systems in the short run. ${ }^{36}$ These two visions of development are not necessarily incompatible, and in many respects it is not an either/or choice for developing countries, particularly least developed countries requiring the potential outcomes generated by both. But there is an important distinction between them and in the context of limited aid resources and necessary development choices the privileging of one over the other has significant consequences for resource allocation and the development priorities of aid recipient states. It seems clear that while there is still a substantial rhetorical commitment to the MDGs, in fact donors are increasingly channelling aid funds to 'big development' projects.

\footnotetext{
35 Michael Woolcock, 'Duelling Development Visions: Shaping the World Bank Future' Let's Talk Development: World Bank Blog http://blogs.worldbank.org/developmenttalk/what-exactly-isdevelopment (accessed March 2013).

36 Woolcock, 'Duelling Development Visions.'
} 
Launched in 2000 the purpose of the MDGs was to mobilise funds, political will and interagency collaboration to address what were seen to be the eight most pressing concerns facing the project of development: poverty and hunger, primary education, gender equality, HIV/AIDS, child health, maternal health, the environment, and partnership. The MDGs generated a significant increase in funding to certain areas such as HIV/AIDS, and led to the creation of new development institutions to mobilise funds and generate public-private partnership such as the Global Fund to Fight AIDS, Tuberculosis and Malaria. While some have argued that they represent a significant act of collective political will to alleviating some of the most pressing challenges of human development, more critical studies have demonstrated that efforts to address these goals operated largely within the paradigm of development thinking that prioritised the private sector as the driver of economic growth, and obviously had a one size fits all character. ${ }^{37}$ More importantly, perhaps, the MDGs did not articulate a clear development strategy ('big development'). As Thandika Mkandawire argued the social protection and poverty alleviation focus of the MDGs did not add up to an account of the transformations associated with 'Big Development'. ${ }^{38}$ In this way, some governments felt 'short-changed' - they were being asked to give up on the promise of transformation.

These debates and anxieties over the MDGs are reflected in current lack of consensus about what, if anything, might replace them after 2015. Some, such as Jeffery Sachs, propose the extension of the deadline to $2025 .{ }^{39}$ Others suggest the MDG-Plus approach: a reinvigoration of the current goals or a rejigging of the goals with the addition of new

\footnotetext{
${ }^{37}$ David Hulme and Rorden Wilkinson, 'Introduction: moving from the MDGs to the GDGs: development imperatives beyond 2015,' in Rorden Wilkinson and David Hulme eds., The Millennium Development Goals and Beyond: global development after 2015 (Abingdon: Routledge, 2012), pp. 1-15. For a critical account see Ashwani Saith, 'From Universal Values to The Millennium Development Goals: Lost in Translation,' Development and Change 37:6, 2006, pp. 1167-1199. For critical discussions of particular goals see Maxine Molyneux, 'The Chimera of Success: gender ennui and the changed international policy environment', in Andrea Cornwall, Elizabeth Harrison and Ann Whitehead eds., Feminisms in Development: contradictions, contestations and challenges (London: Zed, 2007) pp. 227-40, Sophie Harman, The World Bank and HIV/ AIDS: setting a global agenda (Abingdon: Routledge, 2010), and Peter Newell, Globalization and the Environment: capitalism, ecology and power, (Cambridge: Polity, 2012).

38 Thandika Mkandawire, 'Social Sciences and the Next Development Agenda,' Forum for Development Studies 35:1, 2007, p. 9. See also Charles Gore, 'The MDG paradigm, productive capacities and the future of poverty reduction,' IDS Bulletin 41:1, 2010, pp70-79.

39 Andy Sumner and Meera Tiwari, 'After 2015: what are the ingredients of an 'MDG-Plus' agenda for poverty reduction?’ IDS Bulletin 41:1, 2009, pp. 834-843.
} 
goals. ${ }^{40}$ Popular arguments have clustered around the need to green the MDGs and to link the post-2015 agenda or any goals arising concretely with efforts towards sustainable development and addressing climate change. ${ }^{41}$ The 2008 French Sarkozy Commission on the Measurement of Economic Performance and Social Progress called for a need to consider human wellbeing alongside more traditional development markers such as growth. ${ }^{42}$ This in turn has generated a greater reflection on the role of wellbeing in development and how this can be incorporated into the MDG-Plus agenda. ${ }^{43}$

At the same time, however, we have seen a much greater emphasis on some of the elements of 'Big Development', notably infrastructure in the classical sense of transport, public works, and public utilities combined with technology and communication. Infrastructure was a core component of development right from its origins, but from the mid-1980s its significance declined. The impact on indigenous people and the environment of large-scale infrastructure projects, particularly dams, came under increasing scrutiny as a result of NGO campaigns. ${ }^{44}$ Infrastructure projects had a pretty poor record in terms of sustainability and development impact. The return to large-scale infrastructure based projects was signalled under ex-President of the World Bank Robert Zoellick's emphasis on 'modernisation'. This involved the need to be 'client focused' and stressed the delivery of 'transformational projects. ${ }^{45}$ There has also been a renewed emphasis placed on infrastructure by the Bank's key shareholders, the G20, and Bank staff. ${ }^{46}$ In 2010 the Bank

\footnotetext{
40 See Jan Vandemoorlele and Enrique Delamonica, 'Taking the MDGs beyond 2015: hasten slowly' IDS Bulletin 41:1, 2010, pp. 60-69, Selim Jahan, 'The MDGs Beyond 2015,' IDS Bulletin, 41:1, 2010, pp. 51-59, and Myles A. Wickstead, 'Holding on to the MDGs (for now),' IDS Bulletin 41:1, 2010, pp123-126.

${ }^{41}$ Frauke Urban, 'The MDGs and beyond: can low carbon development be pro-poor?' IDS Bulletin 41:1, 2010: pp. 92-99.

42 Joseph Stiglitz, Amartya Sen, and Jean-Paul Fitoussi, Report by the Commission on the Measurement of Economic Performance and Social Progress, 2009 http://www.stiglitz-senfitoussi.fr/documents/rapport anglais.pdf (accessed February 2013).

${ }^{43}$ Allister McGregor and Andy Sumner, 'Beyond business as usual: what might 3D wellbeing contribute to MDG momentum?' IDS Bulletin 41:1, 2010, pp104-112; Sumner and Tiwari, 'After 2015.'

${ }^{44}$ Bruce Rich, Mortgaging the Earth: the World Bank, environmental impoverishment and the crisis of development (London: Earthscan, 1994); Jonathan A. Fox and L. David Brown eds., The Struggle for Accountability: the World Bank, NGOs, and grassroots movements, (Cambridge, MA: The MIT Press, 1998).

45 Robert Zoellick, 'Transcript of opening press conference with World Bank Group President Robert Zoellick,' 2012, http://web.worldbank.org/WBSITE/EXTERNAL/NEWS/0 „,contentMDK:23175789 pageP K:64257043 piPK:437376 theSitePK:4607,00.html (accessed July 2012).

46 Robert Zoellick, 'Transcript: Development Committee Press Conference,' 2012, http://web.worldbank.org/WBSITE/EXTERNAL/EXTABOUTUS/ORGANIZATION/EX
} 
'positioned support for infrastructure as a strategic priority in creating growth opportunities. ${ }^{, 47}$ Bank staff claim that countries, particularly African countries, have long been asking for investment to support infrastructure projects.

There is certainly more stress on infrastructure as measures by aid provision. Between 2008-2011 World Bank regional lending for infrastructure projects reached US\$600 million per year. ${ }^{48} \mathrm{~A}$ look at the aggregate figures suggests that OECD DAC aid commitments for energy, for example, have risen fourfold 2000-2011, while total ODA has risen by less than two and a half fold. Multilateral lending for energy has similarly increased four and a half times over the same period, with a similar increase in lending for transport and storage. ${ }^{49}$ Similar conclusions can be drawn from the data on regional lending. Total OECD DAC lending to Africa rose just over 20\% 2007-2011, but lending for Energy rose about 50\%. In comparison a focus on one area of human development - Health, Nutrition and Population - spending suggests a slight decline in health spending, and a significantly lower number of projects in comparison to infrastructure programmes in $2012 .{ }^{50}$ In the aggregate, the World Bank Group's infrastructure commitments increased six fold 20002010.

The resurgence of infrastructure spending can be attributed to many factors. The growth of goal-orientated strategies since 2000 has generated mixed results and importantly has highlighted gaps in development spending needed for their successful realisation. For example, development strategies to combat maternal mortality rest on effective health systems, working roads, medical procurement and delivery structures, information technology and communication, and available energy resources that make up a country's infrastructure. This process of reflection and 'learning' takes place in a wider context. Three issues seem important here. First, infrastructure investment has become increasingly intertwined with discussions of national economic growth and job creation within developed states (for example, President Obama stressed the importance of infrastructure investment

TPRESIDENT/EXTPASTPRESIDENTS/EXTPRESIDENT2007/0,,contentMDK:23178466 $\sim$ menuPK:64822279 pagePK:64821878 piPK:64821912 theSitePK:3916065,00.html (accessed July 2012).

${ }_{47}$ World Bank, Transformation through Infrastructure, (Washington: World Bank, 2012), p1.

48 World Bank, Transformation through Infrastructure, p35.

${ }^{49}$ Data from OECD Qwids at: http://stats.oecd.org/qwids/

${ }_{50}$ World Bank, 'Projects and Operations: Health System Performance,'

http://www.worldbank.org/projects/search?lang=en\&searchTerm $=\&$ theme_exact $=$ Health system performance (accessed July 2012). 
in his 2013 State of the Union Address). Second, as noted above, infrastructure fits with Lin's model of 'new structural economics' and an emphasis on bolder, more transformative projects. Finally, and crucially, the development success of China is important here, as part of the explanation for its success is often understood to be related to substantial investment in infrastructure.

\section{Changing donor landscape}

The total volume of development assistance has increased significantly since 2000 . Alongside this, however, there has been a significant change in the donor landscape facing aid recipient states - what Woods has called a 'silent revolution. ${ }^{51}$ A recent ODI study concluded that from 2000-2009 'non-traditional' aid flows increased from 8.1\% of total flows to $30.7 \% .^{52}$ These 'non-traditional' flows include aid from non-OECD DAC states, climate finance funds, philanthropists and global funds. While the impact of these nontraditional flows varies from country to country, in general their growing importance has created what the authors of the report call a 'new age of choice' for developing countries. ${ }^{53}$ This in turn has very significant implications for relations between aid recipient states and 'traditional' bilateral and multilateral aid agencies.

The most significant non-OECD DAC donor is, of course China, although there are notable others including Saudi Arabia, Kuwait, Brazil and South Africa ${ }^{54}$ For some of these donors, especially China, generating accurate and comparable data is difficult, partly because of a lack of transparency, partly because funds are provided from a variety of sources and partly because China does not categorise its aid according to OECD criteria. ${ }^{55}$ According to the narrowest definition of aid (that of significantly concessional flows) China is a relatively small provider (about $\$ 2$ bn in 2010 compared to about $\$ 30$ bn from

\footnotetext{
${ }^{51}$ Ngaire Woods, 'Whose aid? Whose influence? China, emerging donors and the silent revolution in development assistance,' International Affairs 84:6, 2008: 1205-1221.

52 Romilly Greenhill, Annalisa Prizzon and Andrew Rogerson 'The Age of Choice: developing countries in the new aid landcape,' ODI Working Papers, Issue 364, 2013.

${ }^{53}$ Romilly Greenhill, 'The Age of Choice: Cambodia in the New Aid Landscape,' ODI Research Report, January 2013; Annalisa Prizzon, 'The Age of Choice: Zambia in the New Aid Landscape,' ODI Research Report, January 2013.

${ }^{54}$ Woods, 'Whose aid? Whose influence?'

55 Deborah Brautigam, "Aid "with Chinese Characteristics": Chinese Aid meets the OECD-DAC Regime', Journal of International Development 23: 5, 2011, pp752-764. See also Austin Strange et al, 'China's Development Finance to Africa: a media-based approach to data collection', Centre for Global Development Working Paper 323, Centre for Global Development, April 2013.
} 
the US). However, when other flows such as export credits and natural resource back credits are included the figure rises significantly (\$5-6bn in 2010). In addition China provides very significant quantities of foreign direct investment (perhaps as much as $17 \mathrm{bn}$ in 2010). ${ }^{56}$ Nearly half of all China's foreign assistance goes to Africa, but it is not just in terms of aid that China has become increasing significant on the continent. ${ }^{57}$ China's imports from Africa totalled nearly $\$ 120 \mathrm{bn}$ in 2011 and China’s exports to Africa totalled over $\$ 80 \mathrm{bn} .{ }^{58}$ China is now the second largest trading partner with Africa (after the US). ${ }^{59}$ China is also an important supplier of military equipment and training to a number of African states. ${ }^{60}$ China's position as an aid donor is notable for its exception to the current development project rules. It is not a DAC donor, which means it does not sign up to the Paris Declaration commitment to partnership and country ownership of development programmes. Its aid also comes with few political and economic conditions attached to it (with the exception of asking African aid recipients to abide by the 'one China principle' no diplomatic relations with Taiwan). ${ }^{61}$ Importantly China prioritises infrastructure financing in its aid portfolio, partly in response to demands from developing countries themselves.

Accompanying the growing aid budget of China has been that of regional development banks. A report by the World Bank Group Alumni - The 1818 Society - noted that despite an increase in investment to the Bank as a consequence of the financial crisis, the International Bank for Reconstruction and Development (IBRD)'s increase in money was $45 \%$ less than the regional development banks. ${ }^{62}$ The African Development Bank, the Asian Development Bank, the European Bank for Reconstruction and Development, and the Inter-American Development Bank all saw significant increases in their capital base

\footnotetext{
${ }^{56}$ Brautigam, 'Aid 'with Chinese Characteristics'. See also Deborah Brautigam, The Dragon's Gift: the real story of Cbina in Africa, (Oxford: OUP, 2009).

${ }^{57}$ Chris Alden, China in Africa: partner, competitor or hegemon? (London: Zed Books, 2007), p22.

58 TRALAC, 'Africa-China Trading Relationship', Trade Law Centre, University of Stellenbosch, August 2014.

${ }^{59}$ IMF, Direction of Trade Statistics, http://discover.ukdataservice.ac.uk/catalogue/?sn=4745\&type=Data\%20catalogue (accessed May 2013).

${ }^{60}$ Alden, China in Africa, p 25-6.

${ }^{61}$ See Ministry of Foreign Affairs, Government of The People's Republic of China, 'China's Africa Policy', January 2006.

${ }^{62}$ The 1818 Society, The Key Challenges Facing the World Bank President: an independent diagnostic 2012. http://siteresources.worldbank.org/1818SOCIETY/Resources/World_Bank_Diagnostic_Exerc ise.pdf (accessed July 2012).
} 
and their lending rates. ${ }^{63}$ This increase has only been over a relatively short time period, with the greatest increase in regional spending and lending happening from the onset of the financial crisis in 2007. What is notable about the increased spending power of the regional development banks is again the emphasis on infrastructure. Infrastructure makes up 38.1\% of African Development Bank lending. ${ }^{64}$ Two of the top lending sectors within the Inter-American Development Bank portfolio are infrastructure projects on 'Energy' $(17.15 \%)$ and 'Transportation' (14.91\%), the largest portfolio is on 'Reform/Modernization' which refers to public management and government institutions. ${ }^{65}$ The Asian Development Bank similarly shows an emphasis on infrastructure projects such as Energy and Transportation. ${ }^{66}$ The BRICS countries formally agreed to the establishment of a new development bank, a BRICS think tank council and business council at the BRICS Summit in Durban, South Africa, in March 2013. ${ }^{67}$ Since this agreement much has been made about framing the BRICS bank as an alternative or challenge to the dominance of the IMF and World Bank's lending portfolios to low and middle income countries and as a means of influencing reform of decision-making within these institutions. Though a fully functioning BRICS bank may be some time away, it nonetheless suggests these countries want greater influence on decision-making in development and that these they see the BRICS bank as a means of widening their own influence over the developing world.

Another significant change in the development landscape is the growth of private philanthropy in development spending through the Bill and Melinda Gates Foundation (hereafter the Gates Foundation). The Gates Foundation has the largest endowment of any philanthropic organisation in history, has a spending portfolio on global health bigger that the World Health Organisation (WHO), and it finances key development agencies such as the Global Fund and the World Bank. ${ }^{68}$ The Foundation's main emphasis is on innovation, meaning scientific discovery and technological solutions to development problems, and performance funding that responds to effective data. The role and impact

\footnotetext{
63 The 1818 Society, The Key Challenges Facing the World Bank President.

${ }^{64}$ AfDB, 'Projects and Operations - Bank Group Loan and Grant Approval by Sector,' http://www.afdb.org/en/projects-and-operations/ (accessed February 2013).

${ }^{65}$ IADB, 'Approved Projects by Sector,' http://www.iadb.org/en/projects/projects-bysector, 6785.html (accessed February 2013)

66 ADB, 'Project Records,' http://www.adb.org/projects/search/21303 (accessed February 2013)

${ }^{67}$ Fifth BRICS Summit (2013) http://www.brics5.co.za/ (accessed December 2013).

${ }^{68}$ Sophie Harman, Global Health Governance, (Abingdon: Routledge, 2012).
} 
of the Gates Foundation is clear to see in global health financing and delivery; ${ }^{69}$ this is important as models for health financing have often been seen as models to be replicated in other aspects of human development, for example looking to ways in which models of public-private partnerships in financing strategies such as UNITAID could be used to mobilise funds for climate change. ${ }^{70}$ The presence of the Gates Foundation will increasingly be felt with the shifting focus towards agriculture, and most significantly, as indicated in Bill Gates's annual letter in 2012, the support for another green revolution, particularly in countries in sub-Saharan Africa. ${ }^{71}$ The significant funding capacity and scope of the Foundation suggests a new role for private philanthropy that is not only involved in technology investment but has an interest and formative role in the terms of debate in specific areas such as disease eradication and global health priorities for development. In addition, the emphasis on technology and innovation as scientific solutions to development problems challenges development thinking as the domain of economic models of growth but positions the future of the project concretely within the parameters of scientific discovery.

The growth of non-traditional donors, the increased significance of regional development banks, and the re-emergence of private philanthropy through the Bill and Melinda Gates Foundation all present changes in and challenges to the development landscape. Taken together they signal a new form of pluralism and very importantly, a dispersal of authority in terms of who gets to set the development agenda and who has influence over developing states. The significance of these changes may have less to do with the amounts of aid money being provided than in the way it has contributed to an on-going shift in the relationship between western donors and aid recipient states.

\section{Changing aid relationships}

At the very least the new pluralism among aid providers creates more space for developing counties who have some ability to pick and choose from among available donors. This

\footnotetext{
${ }^{69}$ David McCoy and Linsey McGoey, 'Global Health and the Gates Foundation - in perspective' in O.D. Williams and S. Rushton, eds., Partnerships and Foundations in global health governance, (Basingstoke: Palgrave, 2011).

${ }^{70}$ Sophie Harman and William Brown, 'In from the margins? The Changing Place of Africa in International Relations,' International Affairs, 89:1, 2013, pp69-87.

${ }^{71}$ Bill Gates, 'Annual Letter from Bill Gates 2012,' http://www.gatesfoundation.org/annualletter/2012/Pages/home-en.aspx (accessed February 2013)
} 
also reduces the leverage that some of the traditional donors have over development policy in developing countries. There has also been some recognition that aid donors should not exercise the kind of leverage they attempted during the era of structural adjustment. It is possible to see how both of these connect up with the changes we noted above in development thinking about the role of the state and about policy autonomy and flexibility.

China's relations with developing countries, particularly in Africa, can be seen as an embodiment of a series of principles that reflect the way that China itself would like to be treated by western states. China's Africa Policy, codified in 2006, says that its relations with Africa will be guided by four principles: sincerity, friendship and equality; mutual benefit, reciprocity and common prosperity; mutual support and close coordination; and learning from each other and seeking common development. ${ }^{72}$ In practice this has meant no explicit economic and political conditionality (apart from adherence to the one China policy) and treating African governments as legitimate representatives of the interests of their peoples. As a Chinese diplomat at the UN said: 'Externally imposed conditions do not offer genuine solutions to African problems ... The international community should ... fully acquaint themselves with the real circumstances of the African countries, respect their sovereign choices and development strategies and support the continent's efforts to lift itself up by its bootstraps. ${ }^{73}$ Western states and development agencies have often been critical of China's aid provision, precisely because it does not concern itself with issues such as good governance, corruption and human rights and lax monitoring and reporting requirements. $^{74}$

China's increasing involvement with Africa, and the very different way it relates to developing countries poses a challenge to states such as the US, Britain and France who have historically played an important role on the continent. ${ }^{75}$ Western donors too, however, have been moving to redefine their relationship with aid recipient states. By the mid-2000s the conditionality associated with structural adjustment lending was being

\footnotetext{
${ }^{72}$ Ministry of Foreign Affairs, 'China's Africa Policy', January 2006.

${ }^{73}$ Quoted in Drew Thompson, 'US Responses to China's Rise in Africa: Policy and Policy Options', in Marcel Kitissou (ed.) Africa in China's Global Strategy (London: Adonis and Abbey, 2007), p. 54.

${ }^{74}$ Horace Campbell, 'China in Africa: challenging the US global hegemony,' Third World Quarterly, 29:1, 2008, pp. 89-105. See also, Yiagadeesen Sany, 'China's Aid Policy in Africa: opportunities and challenges', The Round Table 99:406, 2010, pp. 5-90. ${ }^{75}$ Julia Gallagher, 'Ruthless player or development partner? Britain's ambiguous reaction to China in Africa,' Review of International Studies, 37:5, 2011, pp. 2293-2310.
} 
replaced by a new language of 'ownership' and partnership. ${ }^{76}$ Processes of reflection and learning explain part of this, as it was becoming clear that conditionality was not a very effective instrument for inducing and sustaining economic policy reform. ${ }^{77}$ But again this also reflects wider changes. Conditionality was becoming seen as increasingly illegitimate and the subject of vociferous criticism by NGOs and campaigning groups. ${ }^{78}$ In addition, as non-traditional donors became more important so western donors have become less and less able to exercise influence over aid recipient states. Finally, of course, the financial and economic crisis has undermined the legitimacy and even plausibility of some of the traditional policy conditions pursued by western donors. In this context the language of ownership has taken on a new significance.

How the development of these new kinds of relationship will play out is also related to debates about aid provision within traditional donors, particularly in the context of economic austerity. Questions are being asked, for example, about why the US government would supply free anti-retroviral treatment for people living with HIV/AIDS in developing countries, but not to American citizens, or why local government budgets are being cut in the UK yet DfID money is being used to support strengthening local government in Pakistan and Jamaica. ${ }^{79}$ Scandinavian countries such as Norway are reinvigorating a focus on performance indicators for aid spending, and in 2012 Germany and Sweden froze all funding to multilateral financing bodies such as the Global Fund. It may also be instructive to note that Japan's aid programme stagnated in the second half of the 1990 s as a result of a prolonged economic crisis. ${ }^{80}$

\section{Development in Transition?}

It is no doubt too early to say for sure what the full significance of these changes will be. It is clear, however, that something potentially very significant is happening. The project

\footnotetext{
76DfID, Partnerships for Poverty Reduction; changing aid 'conditionality' (London: DfID, 2004). http://www.bris.ac.uk/poverty/downloads/keyofficialdocuments/DFID $\% 20$ Aid\%20conditiona lity.pdf (accessed May 2013); Tony Killick, IMF Programmes in Developing Countries: design and impact, (London: Routledge, 1995).

${ }_{77}$ DfID, Partnerships for Poverty Reduction.

${ }_{78}$ Vivien Collingwood, 'Assistance with fewer strings attached' Ethics and International Affairs, 17:1, 2003, pp. 55-67

79 DFID. 'Commonwealth Local Government Good Practice Scheme' https://www.gov.uk/commonwealth-local-government-good-practice-scheme (accessed April 2013)

${ }^{80}$ Williams, International Development and Global Politics, pp. 129-131.
} 
of international development has changed in important ways over the last ten years or so. Development thinking is in a state of flux, but there are important signs that there is recognition of a renewed role for the state, particularly in low and middle income countries, and there now exists a plurality of financing options and sources to support state-led initiatives and programs. States in developing countries are beginning to gain more autonomy from western aid institutions because of such a plurality of aid choice and delivery. A combination of enhanced collective agency by aid recipient countries, and choice in the ideas and sources of income to finance development strategies, has afforded the government and civil society actors of some states the opportunity to select which agencies or donors they borrow money from or 'partner' with: OECD or non-OECD lenders, regional development banks or multilateral financers, private or public funds. While such choice is yet to be fully realized there are indications that states, particularly in parts of sub-Saharan Africa, are savvy to these options and that institutions such as the World Bank are aware of the impact of such options to their lending portfolio and relevance. Developing countries are transitioning from the grip of ownership debates to become potentially more autonomous agents.

The renewed role of the state is not only with regard to the management of international development but its delivery. Low and middle income states find much greater voice in regional development banks than multilateral agencies such as the World Bank and are articulating development strategies through south-south co-operation in, at least, discussions over institutions such as the BRICs bank. Alternative sources of development lending and implementation of 'big' development come from state-owned or stateinvested corporations from China, India and Brazil. The return of the state does not mean an end market-based development, and none of the rethinking going on in the World Bank suggests that the market is not crucial for allocating some economic resources. There is, however, recognition that the state certainly has a more expanded role to play than that envisaged even in the 1990s. In addition, there are important changes in how development interventions are delivered and by whom, how governments articulate their own agendas, how state-owned and invested corporations deliver development, how south-south states co-operate through alternative lending sources, and the role of technology within this.

\section{Conclusion: Questions and challenges}


There are an important set of questions and challenges that arise from this process of transition. Here we identify four. The first is a challenge for students of international development policy and practice: how do we explain why these processes of transformation take place? We have here only hinted at what we think are some of the issues involved: processes of reflection and 'learning' within development agencies, particularly the World Bank, changes in the relative power of new states, particularly China, economic crisis, the changing status of particular development issues, and changes within developing countries themselves. Each of these requires unpacking and the ways in which they are related to one another needs exploring to identify the economic, political and normative drivers of this transition.

A second set of challenges face traditional aid donors and developing countries themselves. The ability of western aid agencies to remain central to the project of international development depends on their ability to adapt to the emerging pluralism, both in the wider donors community and in terms of development policies and practices. Debates within institutions such as the World Bank with regard to Lin's new structural economics suggest a recognition and response to both the changing context of the project of international development and the need to attract lenders in a competing terrain. The challenge for developing countries is to use the growing autonomy some of them have, and the new plurality of aid donors, in ways that are developmentally beneficial. During the Cold War when there was also pluralism among aid donors and when some developing countries had significant autonomy, aid monies were quite often used in ways that did not contribute substantially to the process of development. No doubt with the increasing institutionalization of democracy there is more debate within developing countries about the use of aid in the present period. But it still remains the case that donor pluralism and autonomy cannot themselves generate successful development.

A third challenge is more specific: have developing countries and aid donors learned lessons from past experiences with specific policies and practices? Two stand out here: first the stress on infrastructure and second the increased role for the state in the development process. This is important because as we have already noted both of these were emphasised in international development in the post-war period. The record from this period is very mixed, which is precisely why both were heavily criticised during the 
rise of market-based solutions to the problem of development. ${ }^{81}$ Infrastructure projects were often badly managed and poorly implemented, some were downright wasteful, and the sustainability of infrastructure became a crucial issue as the fiscal situation in many developing countries deteriorated in the 1970s and 1980s. Government intervention in the allocation of economic resources has a similarly mixed record. For some states it was a central part of their economic success. For others it was at least implicated in economic mismanagement, rent-seeking and in extreme cases, full-scale economic collapse. ${ }^{82}$ Again it is likely that the political circumstances in many developing countries are different enough to expect outcomes in the present period to be different. But there is also enough evidence from the past to suggest that there might be important lessons to be drawn about the circumstances in which infrastructure investment and government intervention can be successful.

The final set of questions relate to whether we can imagine these changes unravelling. They are at least partly the product of economic and political processes that are subject to change. An economic crisis in China or another major developing state, for example, may undermine the intellectual and political drivers for some of the changes we have identified. That said we do think the changes we have identified are related and in some ways reinforcing, and in this sense we can expect them to be sustained for some time. If this is right it may represent a significant change in the policies and practices of international development.

\footnotetext{
${ }^{81}$ World Bank, Accelerated Development in sub-Sabaran Africa: an agenda for action (Washington DC: World Bank, 1981).

${ }^{82}$ For one case study see Tony Killick, Development Economics in Action: A Study of Economic Policies in Ghana (London: Routledge, 1978).
} 